\title{
Relationship of emotional intelligence of adolescents with selected personal social variables in authoritarian parenting style
}

\author{
M. UMA AND L. UMA DEVI
}

Received: 08.08.2013; Revised: 01.09.2014; Accepted: 15.09.2014

See end of the paper for authors' affiliations

\section{UMA}

Department of Human

Development and Family Studies,

College of Home Science,

Acharya N.G. Ranga Agricultural

University, HYDERABAD (A.P.)

INDIA
ABSTRACT : Parents occupy the most important place in the perceptual world of the child, in spite of rapid changes within the modern family, parental disciplining is still considered very essential for building healthy emotionality and personality of the child. It has generally been observed that in addition to genetic factors, child rearing practices playa vital role in the development of a child particularly the disciplining practices are considered more important. The present study was taken up to examine the relationship between emotional intelligence and selected personal social variables in authoritarian parenting style. The sample comprised of 40 parents adopting authoritarian parenting style and their children between the age range of 15-17 years from the city of Visakhapatnam of Andhra Pradesh. The parental interactional style questionnaire developed by Vivekan Reddy (1996) was used to know the authoritarian parenting style adopted by the parents. Emotional intelligence inventory developed and standardized by Uma Devi (2003) was used to find out the emotional intelligence levels of the adolescents. Results of the study revealed that in the authoritarian parenting style, most of the adolescents had average levels of emotional intelligence. It was interesting to note from the co- relational analysis resulted that social variables like mother's education, income and the child's age were found to have positive and significant relationship with the dimensions of emotional intelligence like impulse control and optimism. Surprisingly variables like family type, family size, caste, mother's income and child's birth order had significant but negative relationship with the emotional intelligence dimensions such as assertiveness, self actualization, empathy, reality testing and happiness.

KEY WORDS: Authoritative parenting, Emotional intelligence, Stress management, General mood

- HOW TO CITE THIS PAPER : Uma, M. and Devi, L. Uma (2014). Relationship of emotional intelligence of adolescents with selected personal social variables in authoritarian parenting style. Asian J. Home Sci., 9 (2) : 345-351. 